\title{
Crossroads in European Union Studies
}

Lynggaard, Kennet; Löfgren, Karl; Manners, Ian James

Published in:

Research Methods in European Union Studies

Publication date:

2015

Document version

Publisher's PDF, also known as Version of record

Citation for published version (APA):

Lynggaard, K., Löfgren, K., \& Manners, I. J. (2015). Crossroads in European Union Studies. In K. Lynggaard, I. Manners, \& K. Löfgren (Eds.), Research Methods in European Union Studies (pp. 3-17). Palgrave Macmillan. Palgrave Studies in European Union Politics http://www.palgrave.com/page/detail/research-methods-ineuropean-union-studies-kennet-lynggaard/?K=9780230363052 


\section{Contents}

List of Tables, Figures and Boxes

vii

Notes on Contributors

\section{Part I Overview}

1 Crossroads in European Union Studies Kennet Lynggaard, Karl Löfgren and Ian Manners

2 Methodology in European Union Studies Ben Rosamond

3 European Union History Ann-Christina L. Knudsen

\section{Part II Micro-Analysis}

4 European Identity: Conflict and Cooperation Angela Bourne

5 People and Social Groups in the European Union Michael Strange

6 Single Policy Study: Three Variations in Design Annica Kronsell and Ian Manners

7 Analysing European Discourses Amandine Crespy

\section{Part III Meso-Analysis}

8 Studying Agenda Setting Sebastiaan Princen

9 Studies of Bargaining in the European Union Sara Hagemann

10 Implementation Studies: Beyond a Legalistic Approach Karl Löfgren

11 Analysing Networks

Jenny M. Lewis and Sevasti Chatzopoulou 
vi Contents

12 Visual Primes and European Union Identity: Designing Experimental Research

Laura Cram and Stratos Patrikios

13 Europeanisation

Theofanis Exadaktylos and Claudio M. Radaelli

\section{Part IV Macro-Analysis}

14 The European Union in Global Politics: Normative Power and Longitudinal Interpretation Ian Manners

15 The Blurred Boundaries and Multiple Effects of European Integration and Globalisation Kennet Lynggaard

16 Hard and Soft Governance Martino Maggetti

17 Political Parties and the European Union Magnus Blomgren

18 Studying European Union Attitude Formation Using Experiments

Julie Hassing Nielsen

19 European Union Studies and the New Regionalism Alex Warleigh-Lack

20 Research Strategies in European Union Studies: Beyond Dichotomies

Ian Manners, Kennet Lynggaard and Karl Löfgren 


\section{1 \\ Crossroads in European Union Studies}

Kennet Lynggaard, Karl Löfgren and Ian Manners

\section{Aims and ambitions}

EU studies is at a crossroads where the many disciplinary interests in Europe meet, as well as temporally where the past weaknesses of methodology meet the future challenges of a new research agenda on Europe. These weaknesses emanate from a number of traditional research design dichotomies in EU studies:

- Research ontology. Do we approach our research through rationalist or constructivist assumptions about EU affairs?

- Research epistemology. Is our ultimate knowledge ambition to formulate explanatory theories capturing EU affairs? Or is our research a process of conceptual (re)constructions aimed at understanding EU affairs?

- Research methodology. Do we best capture EU affairs through positivist and deductive research strategies, or through interpretative and inductive processes?

- Research methods. Do we prefer quantitative or qualitative research methods and data?

We need to deal with, and seek to overcome, such traditional dichotomies to meet the future challenges of a new research agenda on Europe. Scholars within EU studies have thus become increasingly preoccupied with epistemological issues when conducting research on EU affairs (for discussions, see Manners, 2003; Jupille, 2006). The increased prominence of research on Europeanisation since the 1990s and, though less visible in terms of impact, comparative regionalism perhaps since the mid-2000s, seems to have brought to the fore a scholarly interest in developing more explicit and systematic research strategies, designs and methods within EU studies. The renewed interest in research methodology is largely based on the assumption that research on EU affairs may gain further from drawing on analytical 
strategies and research methods derived from across the social sciences. The complexity of EU affairs calls for research methods known from a number of disciplines and for the further development of cross- or transdisciplinary research designs (e.g. Manners, 2009; McGowan, 2009; Warleigh, 2004). EU studies may in fact be considered as a research area which has been particularly prone to cross-disciplinary dialogue (Rosamond, 2006). And not least, the actual European integration process has now reached a point where more wide-ranging research strategies, designs and methods are needed. This gives reason for stressing the scientific ideal of holism - not necessarily opposed to, yet different from, emphasising, for instance, model building and parsimony.

The argument of this book is therefore that research strategies, designs and methods from across the social sciences can, and should, be applied in research directed at EU affairs. Against this backdrop, the purpose of this volume is threefold:

- to provide a state-of-the-art examination of social science research designs in EU studies;

- to provide innovative guidelines for the advancement of research designs in EU studies;

- to move the study of EU research beyond the dichotomies of the past towards a new agenda for research on Europe.

Research methodology is understood as a concern with research strategies, designs and methods. The focus is thus on the principles and procedures guiding research designs and on the research techniques used for specific research purposes. This volume essentially addresses the 'how to study...' questions in EU studies. The questions asked are: how do we conduct research into EU affairs? How can the broader social sciences contribute to the advancement of research designs in EU studies? And how can we move beyond the traditional research dichotomies in EU studies?

\section{Characteristics and challenges in EU studies}

EU studies has perhaps, more than any other sub-discipline, been acutely aware of the too-many-variables-too-few-cases, or the so-called ' $n=1$ problem' (Hix, 2005). This awareness has been present right from the earliest and defining research addressing European integration, which was indeed very much aware of, on the one hand, the exceptionality, or sui generis, of the research object and, on the other hand, the academic desire for comparative cases.

It could be argued that the economic and political integration that took place in Europe during the 1950s, most notably within the European Coal and Steel Community, but also in the Nordic Council and the Council 
of Europe, should be compared with integrative processes in the United Nations, the Americas, the Eastern Bloc, or even the Nasserian collaboration between the Arab states. Alternatively, it could be compared with historically remote eras such as the Carolingian Empire or the Ming Dynasty (Haas, 1961). With varying emphases, such comparisons demonstrate that the political and economic integration in Europe entails a number of unique economic, institutional and social characteristics, making comparisons extraordinarily challenging. This has, however, not prevented EU scholars from looking for more suitable comparative cases and conducting various types of comparisons.

Since the 1990s, many EU scholars have abandoned the approach of studying the EU as an international organisation and instead turned to comparing EU affairs with national political, economic, social and legal processes and systems in both the EU member-states and states outside of the EU. Recently, perhaps since the mid-2000s, we have also seen a revived trend towards comparative regional integration studies, including comparisons of the European integration with other integrative projects such as North American Free Trade Agreement, Association of Southeast Asian Nations and Mercado Común del Sur (i.e. the Southern common market) in South America (Laursen, 2003; Warleigh, 2006).

One can argue that the uniqueness of European integration, or indeed EU studies, puts EU studies in an exclusive position to both carry research designs known from the social science disciplines into EU studies, but also to return the favour by inventing novel research approaches in the social sciences. Again, EU studies appears to be in a favourable position particularly regarding the development of more cross- and transdisciplinary research methods that may find use in other areas of study, such as comparative regional integration and international politics. In fact the rise of the Europeanisation research agenda seems, at least in part, to have involved a revival of the study of EU affairs among political scientists, legal scholars and economists otherwise mainly interested in national political systems, law and economics. To be sure, the point is not whether, or possibly to what extent, the research object of EU studies represents an $n=1$ problem. Our point is that the acute awareness of the $\mathrm{n}=1$ problem makes EU studies a research area suitable for innovative research designs. If anything, the awareness of this defining characteristic of EU studies has become even more pronounced over time. At the same time, the advancement of more inclusive and empirically sensitive research designs directed at the study of EU affairs gives rise to a number of empirical, theoretical and methodological challenges.

\section{Empirical challenges}

One aim of this book is to contribute to the development of cross- and transdisciplinary research methodologies based on the acknowledgment that 
such research approaches are needed in the undertaking of generating more ample knowledge of EU affairs. In that sense, the preference given to crossand transdisciplinary research strategies, designs and methods is essentially based on an empirical argument.

Developments in EU affairs over the past 20-30 years have increased the need for cutting across disciplinary lines. European integration has proceeded in terms of legal, political, economic and social integration. For instance, in legal terms, several treaty revisions and, most recently, the Lisbon Treaty, have expanded the jurisdiction and the competence of EU institutions. New political institutions have seen the light of day including a wide range of independent agencies (Borrás et al., 2007). EU institutional actors have also been subject to massive changes in terms of composition and competences - for example the European Parliament and the European Commission. Economic integration has taken place most notably through the establishment of the internal market and the European Monetary Union including the institutional innovation of the European Central Bank. Similarly Europe has also experienced integration in terms of the development of European societal identities. It would be wrong to claim that national loyalties and identities have been transferred to Europe in any all-embracing and straightforward manner as early theorisations of European integration would lead us to expect. However, multiple identities have developed among European citizens including 'feelings of belonging', not only to national and local communities, but also to Europe. This is particularly so among European elites (Checkel and Katzenstein, 2009). On top of the 'deepening' of European integration, we have also seen a 'widening' of the EU since the early 1980s, where the number of EU member-states has grown from nine to 28 , a growth we have almost certainly not seen the end of.

With European integration also follows two other significant real world developments pushing for a departure from research strategies, designs and methods derived from a single social science discipline. The EU has growing importance for both global and national political, social, economic and legal matters. The significant empirical insights gained on the implications of European integration in national political and economic systems have, since the end of the 1990s, provided us with two important lessons. First, European integration is rarely the sole source of change in national societies (Lynggaard, 2011). Second, the implications of European integration are not confined to any one societal arena and expand, for instance, into judicial systems, public policies and administration, economic policies and state-civil society relationships (Ladrech, 2010; Graziano and Vink, 2007). In the global arena, the implications of European integration also transcend academic disciplines. Think of the involvement of the $\mathrm{EU}$ in one of the most pressing global issues for the past ten years: climate change. The nature of EU's involvement in global climate 
change issues clearly transcends the classical disciplines of economics, legal studies, international politics, comparative politics, sociology and public policy.

This development does not mean that we suggest that European integration is a linear integration process towards an ever closer union. Our point is that integration has proceeded in Europe and none of the mentioned aspects of European integration have taken place independently of each other. And we need to cross and transcend disciplinary lines to appreciate these developments.

\section{Theoretical challenges}

Theoretically, we wish to transcend the divides between frameworks directed at either international and domestic practices. Furthermore, we wish to go beyond the theoretical literatures often associated with particular social science disciplines such political science, economics, legal studies, sociology and history. Overall, we can identify a couple of important challenges in EU studies that surpass our standard disciplinary frameworks.

First, many of the political science approaches to EU studies, such as comparative politics, international relations and public policy, maintain sharp distinctions between their theoretical approaches, and there is a tendency within the monodisciplinary approaches to only include empirical problems which fit their own 'paradigms'. Consequently, the international relations tradition tends to emphasise the role of intergovernmental negotiations, the comparative politics tradition the 'state-like' characteristics of the EU (Warleigh-Lack and Rosamond, 2010), while traditional domestic public policy research tends to treat the $\mathrm{EU}$ as some vague external factor affecting national public administrations and policies.

Second, the exclusive character of the design of EU's institutions, including the rare checks-and-balance system between the actors, and the often technocratic decision-making processes challenge our traditional perceptions of a democratic system. While it is increasingly difficult to maintain a distinction, for example, between legal and political issues and between political and economic issues within national political systems, these distinctions are close to indivisible in the EU system.

Third, although there is always a tension between analytical, normative and prescriptive tensions in all fields of social science, this tension is possibly more present and explicit in the field of EU studies. The text-book distinction between policy analyst and policy advocate is quite blurred within EU studies. The academic analytical work is very close to the actual everyday practice of the policy actors, and vice versa; the community of EU policy analysts has to a large extent adopted the cognitive and normative discourse of the academic community. 


\section{Methodological challenges}

A number of the well-known methodological divides within the social sciences can also be identified within EU studies. These divides are probably most clearly exposed in the rationalist/constructivist paradigmatic dispute, which was widely used to characterise two conflicting approaches to EU studies in the 1990s. What became clear, as the 1990s came to an end, was that rationalist and constructivist approaches were supplying complementary perceptions of EU affairs, rather than representing two fundamentally adversarial schools of thought. The 2000s have thus been characterised by reconciliation and bridge building attempts, often by means of collective research endeavours in the shape of edited collections (Schneider and Aspinwall, 2001; Checkel, 2007), special issues (Jupille et al., 2003; Rittberger and Stacey, 2003) or 'forum discussion' (Checkel and Moravcsik, 2001). Yet, regardless of the good intentions, most often reconciliation meant a submission of selected constructivist research themes under a rationalist research paradigm.

A second divide appears between hypothetical-deductive (theoretically driven) and analytical-inductive (empirically driven) research purposes. On the one hand we find basic methodological set-ups which theoretically test derived hypotheses against a collection of empirical data. On the other hand there is the more open analytical-inductive set-up, which approaches empirical phenomena in order to observe common patterns and develop, for instance, concepts, categories, typologies and sometimes theoretical propositions. This divide is probably also most clearly exposed in the rationalist/constructivist distinction, wherein rationalists tend to employ hypothetical-deductive methodologies and constructivist lean towards more analytical-inductive set-ups. However, we have also witnessed how constructivists engage in developing and testing hypotheses. The development of testable hypotheses and theoretical causal claims is based on the scientific ideal that research should be reproducible and portable into other research areas. Undoubtedly, this ideal has the upper hand in social science and sometimes also imposes particular scientific requirements on the more interpretative research traditions. The development of testable hypotheses and theoretical causal claims is thus often - rightly or not - seen as a measurement of the maturity of a research area or the 'normalisation' of otherwise dispersed research efforts. Moreover, the editorial norms of social science journals also reflect this and seem to require, or at least prefer, a 'presentation of research results' along a certain template: research question, theoretical framework, (perhaps) method, (empirical) analysis and conclusion (Lynggaard, forthcoming). So even though the evolution of new social science research fields, transdisciplinary or not, are supposed to follow their own trajectories, they are in terms of assessment inevitably mirrored against the 'normal' social science (Manners, 2003: 71-3; 2007: 90-1). 
However, regardless of scholarly preferences and norms of conveying research results, research practice still tends to cut across this divide. Even when research is presented as a test of a clearly formulated hypothesis, the preceding research process will almost certainly have involved several attempts of formulating alternative research questions, hypotheses and interpretations of data. Equally, the actual analytical-inductive and interpretative research processes may in fact not be explicated at all in the final publications, but rather be presented as the research results of a more straightforward, linear method. Sometimes hypothetical-deductive methodologies are seen as having their strengths in more well-developed and theorised research areas, whereas analytical-inductive methodologies may be appraised for their ability to develop new concepts, research questions and indeed research areas.

The central claim of this book is, however, that in practical research work these dichotomies are often either artificial or should be conceived as continuums that research activities may be placed along, just as researchers may move back and forth on these continuums during the research process.

\section{Why a problem-solving approach?}

Rather than taking a point of departure in theoretical or methodological approaches we have chosen a 'how-to-study' angle. By this we mean how scholars go about studying empirically some of the most urgent research question in EU studies. We have in this volume sought to do this by focusing on what we perceive as some of the most predominant research questions in EU studies. Research questions tend to cut across one, or more, of the abovementioned artificial empirical, theoretical and methodological divides. Any single study within a certain research area may confine itself to a particular disciplinary approach and research methodology. Still, the vast majority of single studies, at least those with some empirical concern, cut across the divides. Equally, any literature grouped around a central research question will be characterised by some level of research plurality, and indeed a fairly high level of plurality. This also means that we suggest that research pluralism tends to favour more holistic and inclusive research. It is, of course, possible that different research designs generate competing findings and conclusions. However, we propose that most often dissimilar research designs, directed at a common research question, enable us to produce complementary findings and conclusions (see Tarrow, 2004). And even so when research results are presented antagonistically.

\section{Outline of the book}

The remainder of this chapter sets out how the book is organised. In our selection of analytical strategies we were concerned with a number of issues. First, we wished to include studies from the micro-, meso- and macro-levels 
of European integration, and not to reduce EU politics to one single level of analysis (see Kalekin-Fishman, 1991). Micro-level analysis, aimed at the study of individual people, policies or discourses, is the subject of Part II. The focus in this section is on identities, people and their social groups, single policy studies, and European discourses.

Meso-level analysis, examined in Part III, is centred on the study of groups of people, institutions or states. The focus of this section is on agenda setting, bargaining, implementation, networks, visual primes and Europeanisation. In Part IV we look at macro-level approaches: systemic analysis of the EU as a political system within a global context. The focus of this section is on the EU as a global actor, European integration and globalisation, hard and soft governance, elections and party groups, attitude formation and new regionalism. Thus, while this variety of analytical strategies does not claim to be comprehensive, it is illustrative of some of the challenges facing EU scholars. This survey of micro-analysis of individual actions, meso-analysis of groups and macro-analysis of system trends suggests that more comprehensive programmes of EU research would need to understand the synergies between these levels in order to advance holistic scholarship.

Second, based on our experience with the field, and for the benefit of early-career researchers, we have also sought to include some of the more 'classical' research problems within EU studies. In this context, the edited collection can also be read as a research review of an existing body of analytical strategies. Finally, and perhaps in contrast to the above, we have also tried to include novel and innovative analytical perspectives on how to go about research in EU studies.

Each contribution will be organised along the following lines: the first section will introduce the research theme in focus. After that section two reviews central research questions and types of theoretical and analytical approaches within the research domain. The third section will discuss the most pressing research design concerns and address how research strategies may be advanced. In doing so, the third section will draw on insights from empirical research in EU affairs, as well as seek further inspiration from research designs in the broader field of social science. The fourth and final section will conclude by outlining directions for innovative research designs. Each chapter will consider both state-of-the-art research designs in terms of efforts to cut across the divides in the literature - including interpretivist/positivist, constructivist/rationalist and qualitative/quantitative and outline guidelines on how to develop further inclusive and empirical sensitive research designs.

The first contribution, in Chapter 2, by Ben Rosamond contains a metareflection on the history and state of academic methodology discussions within the multidisciplinary remit of EU studies. The message this chapter conveys is that although methodological (which concerns more than just research methods) debates are not easily visible within EU studies, there are 
a number of methodological strands as well as implicit understandings for what should guide empirical research within this academic community. The chapter is also written as a defence of methodological pluralism in order to avoid the tragedy of, for example, American political science with one dominant research paradigm.

In Chapter 3, Ann-Christina L. Knudsen is concerned with how historians research the EU's past. She provides an overview of the field of scholarship on the EU's history, and discusses how historians wrestle with issues of narrativity, generalisations and conceptualisations. Overall, the chapter explores key dimensions of historical research design by discussing what the knowledge ambition of historical research is, how archives and sources are used for writing the EU's history, and also showing how historical research methods can be applied for example to the making of the common agricultural policy in the 1960s.

Angela Bourne focuses in Chapter 4 on methods employed to address research questions examining the relationship between identification whether at mass or elite, member-state or substate levels - and processes of European integration. The chapter examines key themes and research designs employed in both quantitative approaches that are mostly focused on the impact of identities on support for the EU and qualitative methods employed in studies addressing the impact of the EU on identification patterns in Europe. Comparative and case study research designs are discussed and illustrated with examples from territorial politics within member-states with important identity dimensions.

In Chapter 5, Michael Strange presents some thoughts around analytical strategies for studying people and social groups in the EU. This includes the construction and implementation of EU citizenship rights; the quest for an EU demos; and the emergence of an EU society. Overall, the chapter makes clear that the types of research questions related to people and social groups enable researchers to see the EU as not only a top-down political project but also draw attention to the underlying social processes and practices through which European integration is made possible (and challenged) on an everyday basis.

Single policy studies are used to understand the role of the EU in a wide variety of sectors, together with policy development over time, and often offer public policy prescriptions. Chapter 6, written by Annica Kronsell and Ian Manners, discusses the relevance of single policy studies in EU research and gives examples of how such research can be designed and carried out. The chapter reviews three examples illustrative of how single policy studies can be designed using different approaches in the analysis: multiple streams approach to policy making; comparative hypothesis testing; and feminist institutional theory.

Discourse analysis in European studies can touch upon a large number of issues ranging from the EU as a polity or a global actor, to the constitution 
of a European public sphere, or the role of discourse in the Europeanisation of public policy. Moreover, the study of discourses involves a plurality of methodological and theoretical approaches. Amandine Crespy presents in Chapter 7 four main approaches - content analysis, framing, narratives and critical discourse analysis - as well as typical and possible combinations of various methods and theoretical underpinnings. Throughout, the chapter provides illustrations through research dealing with political debates on the socio-economic dimension of EU integration.

Analytical strategies for agenda setting in the $\mathrm{EU}$ are presented by Sebastiaan Princen in Chapter 8. The central question in agenda-setting studies is why some issues receive attention while others do not. Agendasetting studies may focus on individual issues, or on the composition of the EU agenda as a whole. While most studies look at issues that have made it to the agenda, it is equally important to understand why some issues have not made it to the agenda. The chapter presents a number of research strategies that can be used to study these types of questions, using different types of sources (documents, participants) and approaches (interpretative and quantitative), and discusses their strengths and weaknesses.

Sara Hagemann presents in Chapter 9 some thoughts on how to address bargaining within and between EU institutions by reflecting on recent advancements in both qualitative and quantitative empirical studies of negotiation situations and processes. It also draws on more formal political science approaches to EU actors' decision 'games'. The chapter makes it clear that studies of negotiation games between individual and collective actors are essential to improve our understanding of the political system of the EU. At the same time, the EU is a highly interesting laboratory to test and improve political science bargaining theories in general.

In Chapter 10 Karl Löfgren reviews and discusses the status and future of implementation studies among students of the EU. In the past, this field of research was largely driven by a search for the 'golden independent variable' by means of legalist and top-down compliance approaches. Not only was this search anything but fruitful (with no clear indications of what affects successful domestic implementation of EU law), it also overlooked enforcement and mechanisms at the micro-level of the EU polity. In contrast this chapter presents a few examples of micro cases in order to demonstrate alternatives to the dominant top-down compliance perspective of the past.

Jenny Lewis and Sevasti Chatzopoulou demonstrate in Chapter 11 how social network analysis can be done. Analysing networks is a research method for systematically examining actors' interactions, making it very useful for analysing the EU's multilevel decision- and policy-making arenas. The network method identifies, visualises and renders actors' interactions and power more transparent. Governance networks within the Common Agricultural Policy and national agricultural policy networks are used to 


\section{Index}

Note: The letter ' $t$ ' ' $f$ ' following locators refers to tables and figures respectively.

Acemoglu, D., 292

Acharya, A., 300

Achen, C. H., 148

actors' interactions, 174-6, 181

Adelle, C., 87

Adler-Nissen, R., 223

Advanced Therapies Regulation, 148

affective connotations, 189-90

African Union, 226, 304

agenda setting, $10,12,90-1,123,125$, $128,130-3,175,311,316$

central question, 124

coding, 127-9

constructivist angle, 125

decision agenda, 124

dependent variables, 127

discourse analysis, 127-9

explanatory variables, 127

governmental agenda, 124

historical understanding, 133

interpretative angle, 125

interpretative approaches, 125

interviews, 129-31

non-decisions and, 125-7, 131-2

objective interests, 132

positivist approaches, 125

subjective interests, 132

surveys, 129-31

theory, 125

ubiquitous type of study, 124

agricultural crisis, 39

agricultural exceptionalism, 47

agricultural policy, $176-80$

EU CAP governance network, 176-8

Greek policy network, 178-80

technical complexity of, 177

Albert, M., 145

alcoholism, 126, 131

Aldrich, J. H., 271

Alexandrova, P., 124, 128

Alker, H. R., 19, 26

Almond, G. A., 20, 185
Alter, K. J., 206

Alvesson, M., 229, 230

Ames, R. E., 289

analytical-inductive, 8-9

analyticism, 19, 27

Andean Community, 300

Andersen, M., 88

Andersen, S., 87

Anderson, C. J., 187

Angelescu, I., 222

Angelova, M., 154, 161

APEC, see Asia-Pacific Economic

Cooperation

appropriateness, logic of, 60

Aradau, C., 77

Archive of European Integration, 45

archives, 41-2

of ECJ, 44

institutionalisation of the, 41

of political organisations, 41

polycentric location of the, 43

argumentation, logic of, 223

Arregui, J., 144

ASEAN, see Association of South East Asian Nations

Ashraf, N., 290

Asia-Pacific Economic Cooperation, 300, 304, 306

Aspinwall, M., 8, 306

Association of South East Asian Nations, $5,300-2,304,306$

ATE, see average treatment effect

Atlas.ti, 106, 113, 318

Attina, F., 146, 272

Australia, agenda setting, 130

Austria, neo-corporatist political systems, 240

average treatment effect, 284-5, 287

Aylott, N., 275

Bacchi, C. L., 86, 94

Bache, I., 160, 164, 213, 214, 253, 254 
Bachrach, P., 125

Bailer, S., 145, 148

Banal Europeanism, 185

Banchoff, T., 103

Banducci, S. A., 261, 262

Barabas, J., 287

Baratz, M. S., 125

Bardach, E., 155

Bardi, L., 269

bargaining analyses of, 136

Bayesian applications, 144

confrontational, 143

cross-institutional, 147-9

formal, 138-9, 142t

informal, 148

inter-institutional, 147-9

models, 138

NOMINATE applications, 144,146

procedural models, 138

qualitative, $137,140 t$

quantitative, 137-8, 141t, 144

research in the Council, 143-7

spatial models, $138,147-8$

technical sophistication, 138

voting power indices, 138, 145

Bartholomew, D., 261

Bartolini, S., 38

Basque, 63-5, 315

Bates, R. E., 23

Baudner, J., 212

Baumgartner, F. R., 124, 131

Beach, D., 242

Beck, U., 248

Belgium

environmental directives, 157

federal governance, 174

neo-corporatist systems, 241

trade unions and associations, 111

Benford, R. D., 106, 107, 112

Benoit, K., 147

Berg, E., 162

Berg, J., 290

Bergman, T., 275

Berkhofer, R., 41

Bernier, A., 44

Beyers, J., 63

Bickel, R., 261
Bickerton, C., 223

Bieler, A., 241

Bieling, H. -J., 241

Billig, M. G., 184, 185, 186, 189

Bindi, F., 222

biofuels directive, $86,88,92$

biofuels policy, 92-4

bizarre division of labour, 44

Björkdahl, A., 228

Blackmore, J., 88

Blanco, I., 168, 169

blockmodelling, 257

Blomgren, M., 14, 266, 273, 275, 276, $316,317,318$

Bodner, E., 189

Boerger-De Smedt, A., 37

Bogason, P., 173

Bolkestein directive, 104, 111, 113

Bolleyer, N., 269, 274

Boman, J., 162

Bomberg, E., 174

Bonacich, P., 172

Bonn, U., 73

Boolean algebra, 92

boomerang-spiral model, 223

Borrás, B., 6

Borras, S., 207, 255

Börzel, T. A., 63, 87, 92, 155, 157, 174, 175, 206, 208, 209, 253

bottom-up approach, 211-12, 242

Bourdieu, P., 109, 170, 223, 230, 319

Bourne, A., 11, 55, 56, 63, 64, 77, 311, 315,317

Brass, P. R., 190

Braun, D., 259

Breen, R., 239, 244

Breslin, S., 302

Bretherton, C., 222

Brewer, M. B., 56, 59, 191, 292

Brewin, C., 63

Bruter, M., 58, 59, 60, 184, 185, 186, $188,189,192,283$

Bryman, A., 64, 229, 230, 315

Buettner, T., 73

Bull, M., 212

Bulmer, S., 214

Burchell, J., 228

Bursens, P., 157

Butz, D. A., 188, 189 
Caiani, M., 77

Calhoun, C., 224

Calleya, S., 302

Cameron, F., 222

Campbell, D. T., 291, 292

capital liberalisation, 108

Caporaso, J. A., 186, 215, 298

CAP, see Common Agricultural Policy

Carbone, M., 222

Carey, S., 57, 59, 62, 185, 186

Carlin, R. E., 290

Carolingian Empire, 5

Carrington, P., 257, 258

Carrubba, C. J., 138, 146, 272

Carty, K. R., 274

case study, $11,56,62,64,66,73,88,95$, $97,227-8,230-1,256,315-18$

comparative, 227-8, 256, 315

cross-sectional, 66

CSDP, 95, 97

environmental policy, 97

Seattle to Brussels, 73

use of, 315

Castano, E., 198

Castells, M., 168

Castiglione, D., 56, 189

Castrano, E., 59

CDA, see critical discourse analysis

CFSP, see Common Foreign and Security Policy

Chalmers, D., 289

Chatzopoulou, S., 12, 65, 81, 161, 168, $174,177,315,318$

Checkel, J., 8

Checkel, J. C., 31

Checkel, J. T., 6, 8, 31, 32, 56, 67, 68, $185,190,242,273$

checks-and-balance, 7

Cheneval, F., 74

Chernilo, D., 27

Choi, Y., 298

Christiansen, T., 103, 222, 254

Chryssochoou, D., 24

Cini, M., 56, 256

citizenship, 73-4

disparities in the rights, 73

legal construct of, 73

patriotism display, 76

policy formation stages, 74

weakened labour rights, 74
Citrin, J., 185, 186, 191

civil society, $6,78,83,103-4,115,162$, $164,229,247$

discourse and, 103-4

euro critical, 104

global, 78

representations form, 162

transnational, 247

transnational discourses, 115

Clark, C., 39

classical integration theory, 23, 267

Clift, B., 21

Cobb, R. W., 124

Cochran, M., 229

code book, 106, 110, 113

coded official Commission documents, 128

coding, 110, 113-14, 127-9

Coen, D., 255, 256

cognitive mobilisation, 57

Cohen, A., 38

Cohen, M., 90

cohesion policy, 212, 239

Colebatch, H., 87

COM documents, see coded official Commission documents

Committee of Permanent

Representatives, 38, 137, 178

Common Agricultural Policy, 37, 39, $45-7,171,176-9$

common currency, 261-2

Common Foreign and Security Policy, 283

Common Security and Defence Policy, $86,89,94-7,124,315$

gender sensitivity, 94

military dimension, 94

military institutional feature, 96

single policy study, 94-6

vulnerable women, 96

communicative action, 223

communicative channels, 75

comparative designs, 13, 230, 244-5

comparative hypothesis testing, 11,86 , 90, 97, 315

comparative regionalism, 3, 297-8, 302, 304

comparative study, 301-2, 315

comparative temporal analysis, 13 , 245-6, 316 
competition policy, 38

Connell, R., 95, 96

Considine, M., 130

Constitutional Treaty, 283, 285

constructivism, 31, 223, 273

constructivist paradigmatic dispute, 8

Contemporary European History, 38

content analysis, 12, 60, 62, 106-7, 109-10, 113, 117, 231-2, 273, 317-18

Cooper, A., 124, 298, 302

Cooperation and Conflict, 312

Coppolaro, L., 38

Corbett, R., 148

COREPER, see Committee of Permanent Representatives

Corporate Europe Observatory, 80

cosmopolitanism, 248

Costello, R., 148

Council of Europe, 5

Council of Ministers, 43, 45-6, 175, 177-8, 252, 276

counterfactual analysis, 13, 243-4

Courts of Justice, 254

Cowles, M. G., 92, 208

Cox, G. W., 271

Cram, L., 13, 59, 76, 184, 185, 186, 189, 316,318

Creed, D. W. E., 107

Crespy, A., 12, 102, 104, 105, 107, 108, $113,114,128,311$

Cresswell, J., 230, 231, 315, 316, 317

crisis of belief, 309

critical discourse analysis, 12, 109, 113, 126

critical realism, 19, 32

critical social theory, 13, 109, 224-6, 229

Crombez, C., 148

cross-case analysis, 259

cross-disciplinary dialogue, 4-6, 48,312

Cross, J., 144

CSDP, see Common Security and Defence Policy

cultural diversity, 55, 58

cultural threat, 57-8

Cumbers, A., 78

Curley, T. M., 186

Cyprus, conflict zone, 63
Dalton, R. J., 57, 187

Damgaard, E., 275

Damro, C., 226

Davies, B., 37

Daviter, F., 124, 125

debt crisis, 113, 116

deductive approach, 106, 110, 112-13

deductivism, 23

Degenne, A., 172

Dehousse, Fernand, 44

Dehousse, R., 44, 124

Delanty, G., 185

Della Porta, D., 21, 77, 104

Della Sala, V., 76, 77

De Lombaerde, P., 298, 302, 303

Dembinski, M., 223

democracy, 14, 41, 55-6, 79-80, 104, $169,227-8,266-8,274,289-90$

democratic deficit, 74, 215, 255, 267, 270, 288-9, 291, 304

democratic deliberation, 104, 288

democratic legitimacy, 255, 288

demographic controls, 195

Denmark

banking sector globalisation, 246

biofuels policy, 93

coalition government, 115

environmental directives, 157

European financial integration, 247

institutional reforms, 242

missing border land with Germany, 162

neo-corporatist political systems, 240

Deroubaix, J-C., 106

Deschouwer, K., 274

Deutsch, K., 55, 58, 185, 190

de Vaus, D., 230, 315

de Vreese, C., 271, 282, 283

De Vries, C. E., 57, 187, 188

Diani, M., 173

Dickhaut, J., 290

Dietz, T. M., 269

Díez Medrano, J. D., 62, 63, 66, 103, 107, $185,186,189,190$

Diez, T., 24, 55, 63, 103, 222

diffusion approach, 258, 260

diffusion theory, 256

Dijkstra, H., 124

Di Lucia, L., 92

DiMaggio, P. J., 157 
Dinan, D., 37

directional dependence, 309, 313

Directive of Biotechnical Innovation and

Open Network Provision, 148

discourse analysis

civil society and, 103-4

communicative discourse, 105

conduct of, 110

content analysis, 106

coordinative discourse, 105

critical discourse analysis, 109-10

decisive role, 104

Europeanisation, 104-5

Euroscepticism, 104

Foucauldian vision, 103

frame analysis, 106-8

neo-institutionalism, 105

operationalisation of, 105-6

policy narratives, 108-9

polity and a global actor, 102-3

public policy and, 104-5

quantification of discursive content, 106

discourse-historical approach, 109

document analysis, 133, 232, 246,

318-19

documentary sources, 44-5, 61, 65, 163,

$173,176,319$

Doerr, N., 104, 116

Doidge, M., 300

domestic coalitions, differential

empowerment, 262

domestic differences, 196

Doreian, P., 257

Dossi, S., 206

double hatting, 60

Dowding, K., 27

Dreyer-Lassen, D., 292

Drinkwater, S., 74

Druckman, J. N., 281, 284, 285, 289

Duina, F., 298

Dumoulin, M., 41

Dunning, T., 286

Duschesne, S., 186

Dutch referendum, 284-5

Duverger, M., 269

Dyson, K., 212

Earnshaw, D., 148

Eastern Bloc, 5
Easton, D., 72

Eberlein, B., 253, 255, 256

ECJ, see European Court of Justice

ecological modernisation, 91

economic crisis, 237-8, 309

Economic and Monetary Union (EMU), 247

economic policy, 254

ECT, see European constitutional treaty education, 212, 289

Edwards, E. E., 187, 188

Edwards, G., 143

Egan, M., 237, 256

Egeberg, M., 60, 163

Eichenberg, E., 57

Eichenberg, R. C., 187

Elder, C. D., 124

Elgström , O., 143

Eliassen, K., 87

Elvert, J., 38

enlargement, 55, 113, 138, 158, 222-3, 226-7, 254, 269, 283, 300

Ennser, L., 269

entangled identities, 186

environmental policy, 48, 86-92, 97, 158,260

epistemological, 3, 19, 30-1, 57, 102, $105,109,125,268-9,273,302,311$, 313

EP Socialist Group, 44

EPS, see European public sphere

equilibrium theory, 124

Eriksen, E. O., 75, 288

ESC, see European Social Committee

ethnic symbolism, 190

EULCH, see European Union Liaison

Committee of Historians

EU Military Committee and Military Staff (EUMC), 95

Eurobarometer, 58-9, 62, 66, 187, 194, 311,317

euro crisis, 15, 115, 117

Europa.clio-online, 45

Europe 2020, 207, 306

European Central Bank (ECB), 6

European Coal and Steel Community, 4

European constitutional treaty, 114

European Council, 60, 88, 128, 255

European Court of Justice, 43-4, 48, 206

European External Action Service, 225-6 
European identity (identities)

affective dimension of, 190

alliance strategies, 64

civic conceptions, 59

coherence of civilisational

identities, 67

communal identities, 58, 190

comparative research designs, $62-3$

cosmopolitan identities, 68

cultural conceptions, 59

delimitation of, 67

dependent variable, 60

discourse analysis, 60-1

Eurobarometer data, 58-9

Eurosceptic, 58

in everyday life, 61

exclusive national identities, 58

future-oriented, 60

identity building capacity, 60

identity construction of modern

Europe, 63

identity hegemony, 57

impact of immigration, 61

individuals multiple identities, 56

local identities, 57

marble cake model, 57

multiple, 63

national, 57

negative markers, 61

nested identities, 56

patterns of identification, 60-2

plausible hypotheses, 62

polemics, 55

positive markers, 61

in psychological understanding, 186

racial identities, 56

regional identity, 56

salience of debates on, 55

social model-based identity, 60

socio-linguistic perspective, 60

support for EU, 57-9

variables, 58

Europeanification, 87

European integration

agenda setting, 125

bottom-up, 241-2

cohesion policy, 239

comparative temporal analysis, 245-7 counterfactual analysis, 243-4

deepening of, 6

as discourse, 239

domestic impact, 154, 207, 223

empirical effects of, 206

financial integration, 246

globalisation, 238-9

impact of identity, 57

impact on liberalisation, 244

implications of, 6, 239, 242, 248-9

innovative research designs, 247-9

institutionalisation processes, 247

liberal intergovernmentalism, 238

making of CAP, 45

multi-level politics, 65

myth making, 76

neofunctionalist critique of, 25

net impact of the EU, 239-40

new research into, 47

policy initiatives for, 47

problems of, 26

process tracing, 242-3

shift of loyalties, 55

snobbery, 301

storytelling, 76

supranationalism, 238

temporal comparative analysis, 246

theorisations of, 6

top-down, 241-2

transformative power of, 206

variegated neoliberalism, 241

varieties of capitalism (VoC), 240-1

Europeanisation

alternative designs, 210-14

analytic eclecticism, 216

bottom-up revolution, 211-12

classic design, 208

classic model, $210 f$

curvilinear effects prediction, 209

degree of, 104, 207, 209, 215

democratic outcomes of, 206

differential Europe prediction, 209

discursive dimension of, 104-5

empirical analyses, 215

goodness of fit, 208-10

high adaptational pressure, 209

horizontal Europeanisation, 242

of identities, 104

integration theory, and, 214

limits of, 207 
Europeanisation - continued mechanisms of, 213-14 mixed-method research, 215-16 motivation behind, 207 multi-method research, 215 normative dimension, 215 popularity of the, 208 pre-conditions for, 208 of public communication, 103 rise of the, 5 of social welfare, 283

Europeanity, 310

European Monetary Union, 6 European Movement, 44

European Navigator, 45

Europeanness, 57, 60, 109

European Parliament, 6, 27, 38, 74, 109, $124,136,175,252,255,268,282$

European public sphere, 12, 41, 73, 75-6, 82, 103-4

European Social Committee, 177

European Social Forum, 79-80

European Union Liaison Committee of Historians, 38-9

European Values Survey, 187

Europe/European Convention on Human Rights, 227

Europolis Deliberative Poll, 288

Europub, 104

Euro-region, 162

Euroscepticism, 56, 104

Eurosclerosis, 47

Eurostars, 61, 190

Eurozone crisis, 113-14, 207, 209, 212

Exadaktylos, T., 13, 156, 160, 206, 207, $211,214,223,242,256,317,318$, 319

experimental research, 14, 59, 97, 198, 281-3, 290, 316

benefits, 291-2

blame-avoidance hypothesis, 283

causality study, 292

causal model, 281

deliberation exploration, 287-92

difference-in-difference, 292

different forms of, 286-7

experimental realism, 291

field experiments, 286

legislative voting, 282

matching techniques, 292 mixed-methods designs, 292

mundane realism, 291

pitfalls, 291-2

regression discontinuity designs, 292

second-order election models, 282

state-of-the-art, 281-3

strategic voting, 282

survey experiments, 287

experimental study, 287

experimental treatment, 284, 289-90

experiments, 61, 192, 281-7, 281, 288-9, 291-2, 317

explanatory research, 97, 230-1, 315, 317

Fabre, E., 274

Falkner, G., 87, 92, 158, 256

Farrell, H., 147, 148, 149

Farrell, M., 299

Faust, K., 172, 257

Favell, A., 23, 56, 61, 73, 186, 187, 190

Fawcett, L., 298

Fearon, J., 31, 288

Featherstone, K., 207, 212

Felsenthal, D. S., 145

Femern Belt region, 162-3

feminist institutional theory, $11,86,88$, 90, 97

feminist theory, 95

Fenno, R. F., 275

Ferguson, M. J., 193

Fernandez, R. M., 172

financial sustainability, 240

Finland, neo-corporatist system, 241

Fischer, F., 107

Fishkin, J. S., 288

Fishkin's deliberative polls, 288

Fiske, S., 191

Fligstein, N., 58, 60, 185, 187, 190

Flinders, M., 160, 254

Flockhart, T., 213

Foellesdal, A., 288

foreign policy, 56, 130, 206, 222, 229, 300

F-oriented projects, 207

Forse, M., 172

Förster, M., 73

Fortress Europe, 74

forum discussion, 8

Fossum, J. E., 185, 288 
Fouilleux, E., 105

framing, 12, 60, 80, 93, 105, 107, 109, $112-13,116,128,282-3$

Framing Europe, 107

France

adaptational pressures, 208

centeralised governance, 174

civic and cultural conception of identity, 59

commercial interests, 45

Etatist system, 240

EU economic governance view, 115

language skills, 45

national identity, 62

national sovereignty and cultural heritage, 63

parliamentary debates, 62

referenda debates over the ECT, 115

trade unions and associations, 111

Franklin, M., 57, 271

Friedrichs, J., 314

Fritsch, O., 215

Frognier, A. -P., 187

Füglister, K., 259

functional cue, $189,200 f$

impact of, $196 f-7 f$

Fung, A., 288

Gabel, M., 57, 59, 62, 187, 272

Gadarian, S .K., 282

Gaines, B. J., 287

game theory, 20, 142, 148

Garavini, G., 38, 40

Garcia, B., 124

Garrett, G., 27, 145, 147, 148

Gasperi, Alcide de, 44

Gavin, B., 298

Gaxie, D., 187

Gehring, T., 222

Gellner, E., 185, 190

General Agreement on Trade-in-Services (GATS), 78-80

Genna, G. M., 186, 303

Georgakakis, D., 48, 76

George, A., 224, 227

Gerber, A. S., 286, 287

Germany

adaptational pressures, 208

commercial interests, 45

competitive position of, 240
EU economic governance view, 115

EU environmental policy, 158

European integration, 62

federal governance, 174

language skills, 45

missing border land with Denmark, 162

national identity, 62

neo-corporatist systems, 241

parliamentary debates, 62

social policies, 239

trade unions and associations, 111

Geuijen, K., 133

Giddens, A., 224

Gilardi, F., 256, 258, 259

Gilbert, M., 37, 39

Gilboa, A., 189

Glaeser, E. L., 290

global climate change, 6

globalisation, 10, 13, 21-2, 67-8, 104, 237-49, 266, 298-300, 306,

316,319

globality, 310

global politics

carrot and stickism of financial rewards, 226

causal research design, 224-5

cause-effect explanations, 225

collected works, 222

comprehensive approach, 227

constitutive research design, 224-5

cross-sectional research design, 231

cultural reproduction, 223

forms of power, 225

general overviews, 222

hybrid polity, 221

innovative research designs, 230-2

longitudinal interpretation, 221, 224, 228-30

material incentives, 226

mixed methods approaches, 230-1

normative justification, 224, 226

normative power analysis, 223-30

norms and normality, 221

physical force, 225

promotion of principles, 227

sector-specific research, 222

sequential mixed methods, 231

theoretical and analytical approaches, 222 
global politics - continued

theory development, 222

trinity of power, 225-6

tripartite analysis, 226-7

Gobin, C., 106

Goertz, G., 131

Goffman, E., 106, 107

goodness-of-fit, 157-8, 208-10

Gordon, C., 223

Gould, R., 172

governance

autonomous level of, 255

bottom-up perspectives, 256

closeness centrality, 257

consultation procedures, 256

de-centred process of, 252

degree centrality, 257

diffusion approach, 258-60

ego network analysis, 257

Europeanisation, 253

Euro-polity, 253

fragmented, 253

good regulatory governance, 260

graph theory, 257

hard governance, 255

modes of, 252

multilevel, 87-8, 92-3, 160, 168, 174, $209,239,253-5,260-2$

new modes of, 255

open method of coordination, 256

policy formulation and

implementation, 253

polycentric form, 253

public-private interactions, 252

regulatory state, $253-4$

social network analysis, 258

soft governance, 255

top-down perspectives, 256

governance networks, 12, 162, 169

Gram-Skjoldager, K., 38, 48

Grande, E., 255

graph theory, 172

Graziano, P., 6, 211, 239

Greece, agricultural policy area, 176-80

Green Cowles, M., 92

Green, D. P., 27, 92, 185, 187

green political theory, $88,90-1$

Greve, B., 255

Griffiths, R. T., 40

Gross, E., 223
Guiraudon, V., 23, 73, 187

Gulbrandsen, C., 163

Gutierrez, P., 63, 186

Gutmann, A., 288

Haas, E. B., 5, 25, 26, 55, 185, 238, 297

Haas, P. M., 25, 176

Habermas, J., 56, 104, 185, 223, 230, 288

Hadfield, A., 222

HAEU, see Historical Archives of the European Union

Häge, F. M., 239

Hagemann, S., 12, 136, 138, 144, 149 , $313,316,317,318$

Hajer, M., 86

Hakhverdian, A., 97

Hall, P., 112, 162

Hambloch, S., 38

Hamedinger, A., 163, 164

Hansen, M. J. W., 48

hard governance, 252

Hariri, J. G., 292

Harmsen, R., 56, 103

Harrison, R. J., 24

Haslam, S. A., 186

Hassard, J., 169

Hassin, R. R., 188, 193, 197

Hauray, B., 213

Haverland, M., 207, 239, 242, 244, 269

Hay, C., 18, 30, 105, 239, 313

Hayes-Renshaw, F., 143, 144

Hayward, J., 210

Hazan, R. Y., 276

health, 126, 128, 131, 159, 239, 310

Hedström, P., 213

hegemony, 57, 109, 304

Heichel, S., 87

Heinrich, C., 292

Heisenberg, D., 138, 139, 143, 148

Hellström, J., 188, 270

Helsinki Final Act, 226

Hennessy, A., 124

Hennis, M., 239

Henry, G. T., 92

Heritier, A., 87, 92, 147, 148, 149, 157, 207, 208, 253, 254, 255

Herrmann, R. K., 56, 59, 185

Hettne, B., 299, 300, 303, 305

Hill, C., 222

Hill, M., 156 
Historical Archives of the European Union, 43

historiography, 38, 40, 49

history of the EU, 37, 39, 41-2, 45

access to private archives, 42

archives, 41-2

milestones, 39

progressive narrative of integration, 39

research design, 40-7

sourcing, 42-5

teleological narrative of integration, 39

Hix, S., 4, 74, 146, 147, 148, 253, 268, $270,271,272,273,288$

Hobolt, S. B., 187, 188, 191, 271, 282

Hobsbawm, E., 187

Hoerl, B., 148

Hoffmann, S., 25

holism, 4, 319-20

Holland, J., 229

Hollis, M., 225

Holmes, D. R., 61, 62, 66

Home Style, 275

Hooghe, L., 56, 57, 58, 59, 160, 185, 186, $187,188,190,191,252,254,273$

Hopkin, J., 274

Hosli, M., 145

Howarth, D., 78

Hox, J. J., 261

Høyland, B., 144, 149, 272

Huddy, L., 191

Huntington, S., 67

Hupe, P., 156

hybrid identities, 186

hypothesis testing, $11,86,90,97,315$

hypothetical-deductive

methodologies, 8-9

Ichijo, A., 186

identity politics, 63-4

immigration, 15, 61, 68, 72

implementation, 93, 154-5, 159-60, 162,164

administrative implications, 158

analyses of, 155

analytical lenses of implementation studies, 155

compliance, 156-9

compliance, $159 t$

domestic implementation, 154

EU area based programmes, 163-4
Femern Belt region, 162-3

goodness-of-fit hypothesis, 157-8

innovative roads, 159-61

legal-institutional model, 157-8

legal transposition of EU directives, 156

meta-perspective, 155

methodological approaches, 156

misfit, 156-9

principal-agent relationship, 160

single-market reforms, 157

status and position of, 155

street-level bureaucrats training, 163

top-down approach of, 155-6

transposition, 156-9

Indonesia, Islamic identities in, 189

inductivism, 23

Ingelgom, V. V., 190

Inglehart, R., 57

institutional arrangements, 40, 75, 117

institutionalist migrants, 27

institutional reforms, 242

instrumental connotations, 189-90

integrative habits, 185

interdisciplinarity, 33, 117

intergovernmentalism, 24-5, 155, 238

liberal, 25, 208-9, 241

intergovernmental negotiations, 7, 210

International Criminal Court, 228

International Institute for Social

History, 47

International Organization, 25-6

interpretation

casual, 229

comparative, 316

of EU policies, 160

frameworks for, 47

of gender, 96

of global rules, 163

of history, 62

longitudinal, 13, 221, 224, 228-30, 316

plausible, 62

pluralistic, 229

sui generis, 49

time and space, 114

INTERREG, 162

interviews and surveys, 129-31 


\section{Copyrighted material - 9780230363052}

\section{Index}

Ireland

banking sector globalisation, 246

conflict zone, 63

European financial integration, 247

referenda debates over the ECT, 115

Italy

coalition government, 115

cohesion policy, 239

public budgets and policies, 212

Jachtenfuchs, M., 103, 253

Jackson, P. T., 18, 19, 20, 25, 27

Jacob, P. E., 26

Jacoby, W., 237, 240

Jacquot, S., 211, 306

Jakobsen, M. L. F., 242, 243

Jansen, T., 269

Jeffery, C., 63

Jensen, M. D., 29, 206, 214

Jensen, T., 147

Jenson, J., 76

Jerit, J., 287

Jileva, E., 74

Joachim, J., 223

Jobert, B., 105

Joerges, C., 255

Johansson, K. -M., 87, 269

Johnston, A., 300

joint-decision mode, 255

Jones, B. D., 124

Jones, B. S., 292

Jones, M. D., 108

Jönsson, C., 143

Jordan, A., 87, 88, 92, 253, 254

Jørgensen, K. E., 306, 312

Journal of Common Market Studies

(JCMS), 28

Journal of European Integration History, 38

Journal of European Public Policy (JEPP), 28,240

Judge, D., 148

Jupille, J., 3, 8, 30, 282

Kaeding, M., 155, 158

Kahanec, M., 73

Kaiser, K., 26

Kaiser, W., 23, 32, 38, 39, 40, 41, 48

Kalekin-Fishman, D., 10

Kam, C. D., 289

Kandyla, A., 283
Kantola, J., 87

Karpowitz, C. F., 288, 289

Katzenstein, P. J., 6, 56, 66, 67, 68, 185

Katz, R. S., 267, 274

Kaufman-Osborn, T., 32

Kauppi, N., 40, 48

Kavalski, E., 228

Keating, M., 21, 56, 63

Keck, M., 223

Keeler, J. T., 55

Keene, E., 228

Keil, D., 162

Kelemen, R. D., 215

Kellas, J., 190

Keltner, D., 292

Kemmelmeier, M., 188, 193

Kennedy, D., 63

Keohane, R. O., 31

Kerremans, B., 63

Kerwer, D., 253, 255

Keukeleire, S., 222

Keynesian paradigm, 116

Kim, M. -hyung, 186

Kingdon, J. W., 90, 124, 130, 133

King, G., 18

Kissack, R., 222, 223, 228

Kleine, M., 74

Klijn, E. H., 169

Knill, C., 87, 88, 92, 155, 158, 175, 214, 226, 253, 256

Knoke, D., 256

Knudsen, A. -C. L., 11, 37, 38, 39, 45, 47, $48,87,128,133,312,319$

Knutsen, T. L., 18

Kohler-Koch, B., 253, 254

Kolodny, R., 267

König, T., 147

Koole, R., 274

Koopmans, R., 75, 104, 106

Kopecký, P., 269

Koppenjan, J., 169

Krahmann, E., 223

Kratochwil, F., 314

Kreppel, A., 147, 148, 272, 276

Kristensen, P. M., 29, 206, 214

Kronsell, A., 11, 15, 86, 88, 89, 90, 92, $94,95,97,315$

Kumlin, S., 283

Kurki, M., 225 
Kurzer, P., 124

Küsters, H. J., 37

Kyoto Protocol, 228

Ladi, S., 239

Ladrech, R., 6, 87, 206, 269, 270

Laffan, B., 60, 62, 87, 184, 185, 186

Laitin, D., 186, 187, 189

Lane, J. -E., 143, 144

language barriers, 83

language skills, 45

large-n, 25, 158, 215, 269, 271, 273, 276, $287,315,317$

Larsen, H., 103

Lauder, H., 88, 94

Lauristin, M., 75

Lau, R. R., 282

Laursen, F., 5

Lavenex, S., 174

Law, J., 169

Lawson, K., 267, 275

layered identities, 186

Leblang, D., 282

Lehmkuhl, D., 214, 253, 256

Leith, M. S., 63

Lenschow, A., 87, 88, 158, 214, 255

Lerner, J. S., 292

Leucht, B., 48

Levi-Faur, D., 239, 244, 245

Lewis, J. M., 12, 65, 81, 143, 168, 169, $170,171,315,318$

lexicometry, 106, 117

liberal-constructivism, 223

Lieberman, E. S., 216, 276

Liebert, U., 92, 104

Liefferink, D., 87, 88, 92

Lightfoot, S., 228

Lindberg, B., 273

Lindberg, L. N., 25, 26, 30, 45

Lindseth, P., 38

Lin, N., 170

Lipgens, Walter, 44

Lipset, S. M., 267, 269, 275

Lipsky, M., 160

Lisbon agenda, 207, 306

Lisbon European Council, 255

Lisbon strategy, 111

Lister, M., 73

Littoz-Monnet, A., 124

Lodge, J., 270, 271
Löfgren, K., 3, 12, 154, 162, 214, 309, 312

Lombaerde, P. D., 298, 302, 303

longitudinal interpretation, 221, 224, 228-30

longitudinal studies, 114

Love, G. J., 290

Lubbers, M., 186, 187

Lucarelli, S., 223

Ludlow, N. P., 38, 40, 43, 44

Lukes, S., 126, 132

Lupia, A., 275

Luskin, R. C., 288

Luther, K. R., 266

Luxembourg, 43, 45

Lyengar, S., 291

Lynch, P., 269

Lynggaard, K., 3, 6, 8, 13, 67, 107, 126, $175,213,223,237,239,242,246$, $309,316,319$

Maas, W., 73

Maatsch, A., 106

Macartney, H., 241, 248

Machover, M., 145

MacNaughtan, J., 222

MacRae, H., 95

macro-level, 9-10, 320

Maggetti, M., 14, 252, 254, 255, 256, 258,316

Magnusdottír, G. L., 88

Mahoney, C., 127

Mahoney, J., 131

Maier, M., 282

Mair, P., 215, 269, 274

Majone, G., 190, 253, 256

male-as-norm, 95-6

Manners, I., 3, 4, 8, 11, 13, 15, 56, 86, $89,90,97,103,184,186,189,221$, $222,223,224,225,226,227,228$, 229, 248, 249, 297, 300, 305, 309, $313,315,316,320$

Mansfield, E., 298

Mansholt, Sicco, 46-7

marble cake model, 186

March, J. G., 90

Marcus, G. E., 292

Marcussen, M., 186, 187

Marin, B., 175 
Marks, G., 56, 57, 58, 59, 63, 160, $174,185,186,187,188,190$, 191

Marshall, A., 164

Marshall Plan, 40, 44

Marsh, D., 169

Marsh, M., 270

Martinsen, D. S., 87

Marwell, G., 289

Marx, Karl, 225

masculinity, 96

Mastenbroek, E., 92, 157

Mattila, M., 143, 144, 271

Mattli, W., 307

MaxQDA, 232, 318

Mayer, J. W., 248

Mayntz, R., 169, 175

Mazmanian, D. A., 154, 155

McBeth, M. K., 108

McCabe, K., 290

McCall, C., 63

McCauley, D., 206

McCormick, J., 222

McCubbins, M. D., 271

McDermott, R., 281, 291

McElroy, G., 27, 147

McGarry, J., 63

McGowan, F., 4

McGraw, K. M., 282

McGuinness, N., 87

McLaren, L. M., 57, 62, 184, 185, 186, 187

McNamara, K. R., 76, 189

mechanisms, of Europeanisation, 213-14

Medrano, Díez, 62, 66, 103, 107, 185-6, 189-90, 317

Meehan, E., 77

Meinhof, U., 59, 61

member states, 62, 208

Mendelberg, T., 288

Meny, Y., 87

Menz, G., 240, 241

Mérand, F., 23, 76, 223

Mercosur, 300, 302

Merkel, Angela, 114

Merlingen, M., 222

Merriënboer, J. van, 46

meso-level, 10 methodological challenges, 110-14 coding, 113-14

corpus constitution, 111-12

inductive versus deductive, $112-14$

methodological cosmopolitanism, 248

methodological nationalism, 27, 33, 39, 248

methodological pluralism, 11, 14, 20, 32,66

methodological politics, 30-2

methodology

absence of conversation, 24-32

analyticist, 25

commitments, 30

confusion and conflation, 18

equation with methods, 18

examination of, 21-3

interdisciplinarity, 33

macro-disciplinary norms, 22

mainstreaming, 22-3

neopositivism postulates, 32

neopositivist tenets, 20

pluralism, 20, 30

political methodology, 19

politics of EU studies, 30-2

sociology of knowledge-type investigations, 21

toolkits of techniques, 19

totality of, 19

typology of, 25

Meunier, S., 105, 237, 240

Meyer, J. -H., 38, 41, 48, 75, 133

micro-level, 10, 12, 76, 282

Middell, M., 49

Migani, G., 38

migration, 56

militarism, 96

Miller, G. J., 275, 282

Milligan, J. S., 41

Milner, H., 298

Milward, A. S., 38, 39, 40

Ministry of Rural Development and Food, 179

MINRDF, see Ministry of Rural Development and Food

Miskimmon, A., 223

Mitrany, D., 185

Mittag, J., 38

mixed methods, 60, 66, 149, 230-2, 317-18 
mock referendum, 285

Mols, F., 186

monetary cooperation, 38

monetary union, 47

Monroe, K. R., 20

Moran, M., 254

Moravcsik, A., 8, 25, 31, 32, 45, 208, 238, 288

Morrell, M. E., 289

Morton, R. B., 281, 282, 284, 289, 291

Moschella, M., 124

Moses, J. W., 18

Mourlon-Druol, E., 38

Mudde, C., 269

Muller, P., 105

Müller-Rommel, F., 266

Müller, W. C., 268

multilevel analysis approach, 260

multi-level governance, 174

multilevel research design, 261

multiple streams, 11, 86, 90, 97, 124

multivariate techniques, 261

Murray, P., 23, 301

Mutz, D., 289

NAFTA, see North American Free Trade Agreement

narrative

analysis of, 60

documented, 46

of global social movement, 77

meta-nerrative, 39-40

national identity, 189

policy narratives, 108-9

progressive narrative, 39

shared, 80

teleological narrative, 39

use of, 232

Nasserian collaboration, 5

Natalini, A., 212

national consciousness, 185

national differences, 190-1

national identity, 56, 58, 189-90, 192, 197, 267

nationalism, 27, 33, 39, 190, 248

Naumann, K., 49

Navarro, J., 273

Neal, A., 74

neo-corporatist political systems, 240

neofunctionalism, 24-5, 155, 209 neofunctionalist integration theory, 22 neo-Gramscian studies, 126

neo-institutionalism, 105

neoliberal ideology of competitiveness, 132

neoliberalisation, commonalities of, 241

neopositivism, 19-20, 32

nested identities, 186

Netherlands

centeralised governance, 174

civic and cultural conception of identity, 59

Constitutional Treaty rejection, 283

language skills, 45

neo-corporatist systems, 241

networks

actor network theory, 168

analysis, 171-6

analytical inquiry, 169

betweenness centrality, 172

bottom-up spontaneous action, 173

CAP decision-making network, $177 f$

classification of, $170 t$

concepts and types, 168-70

in-degree centrality, 172

governance, 169

governance networks, 169

managed networks, 172-3

mapping, 171

multilevel governance concept, 174

policy networks, 169-70, 175

resource dependency, 175

SNA approach, 174

social network analysis (SNA) software, 171

social networks, 170

top-down imperatives, 173

Network Society, 168

Neumayer, E., 260

Newell, W., 303

New Handbook of Political Science, 18

Newig, J., 215

new institutionalist theories, 157, 223

Newman, A. L., 255, 256

new regionalism, 10, 14, 67, 297-306,

312-15

benefits of, $299 t$

globalisation-regionalisation matrix, 300 
new regionalism - continued

inter-regionalism, 300

practical difficulties, 302

region-ness continuum, $303 t$

Nielsen, J. H., 14, 59, 281, 287, 312, 316, 317,318

Noël, Emile, 43-4

nomothetic versus idiographic approaches, 23

non-decisions, 125-7, 131-2

non-majoritarian institutions, 254

Nora, P., 41

Nordic Battlegroup, 96

Nordic Council, 4

normative power analysis, 223-30, 227

North American Free Trade Agreement, $5,301-2,304$

Norway, 244

Noury, A. G., 146

Nousios, P., 241

$\mathrm{n}=1$ problem, 4-5

Nvivo, 106, 232, 318

Oberthür, S., 222

O'Carroll, C., 87

Ockenfels, A., 290

OECD, see Organisation for Economic

Co-operation and Development

old age pension and health policies, 239

Oleske, J., 288

Olsen, E. D. H., 288

Olsen, J. P., 90, 94, 157

OMC, see open method of coordination open method of coordination, 174

Orbie, J., 222, 228

ordo-liberal paradigm, 116

Organisation for Economic Co-operation and Development, 245

Organisation for European Economic Cooperation, 44

Origins of European Integration, 39

Ostrauskaite, R., 222

O’Toole, L., 97

Pace, M., 222

Pajala, A., 145

Panke, D., 269

Papadimitriou, D., 207

Papadopoulos, Y., 255

Paris Charter, 226
Paris Memorandum of Understanding, 163

Parks, L., 107

parsimony, 4, 92, 139

Parsons, C., 76

party systems, 269-70

Party Systems and Voter Alignments, 267

Pasquier, R., 206, 211

Passi, A., 77

Pedersen, R. B., 242

Pen, Jean Marie Le, 61

Pentland, C., 24

performative theory of language, 103

Perkins, R., 260

Perkmann, M., 162

Peters, B. G., 123

Peters, G. B., 252

Peterson, J., 155, 174

Petõ, A., 90

Phinnemore, D., 306

Pia, E., 73

Piattoni, P., 160

Piattoni, S., 254

Pierre, J., 252

Pierson, P., 45, 157

plurilingualism, 288

Poidevin, R., 39

Poland

national identity, 62

national sovereignty and cultural heritage, 63

qualitative content analysis, 62

Polanyian double movement, 299

policyagendas.org, 131

policy communities, 116, 133

policy instruments, 39, 89, 156, 258

policy networks, 12, 169-70, 175-6

Political Analysis, 18

political parties, 14, 38-9, 42, 111, 158, 206, 266-76, 316

approach to, 273

arena metaphor, 268

denationalisation, 274

electoral arena, 268

in electoral arena, 270-1

extreme-right parties, 269

far-right parties, 269

federalisation, 274

functions, 267

genealogy of, 269 
green parties, 269

identify a number of challenges, 266 in legislative arena, 268, 271-3

as organisations, $269-70$

party decline debate, 266

principal-agent relationships, 275

role of, 266-7, 274-6

role in the electoral process, 270

vertical relationships, 275

political psychology, 97, 188, 281-2, 285,292

political values, 57, 266

Pollack, M. A., 27, 123

positivism, 225, 273

positivist, $3,10,32,62,102,105,125$, 306, 310-11

possibility principle, 131

Powell, W. W., 157

power politics, 40

Pressman, J. L., 155

Priban, J., 189

Princen, S., 12, 123, 124, 125, 126, 128, $131,144,311,318$

privatisation, 244

probability theory, 145

problem-solving approach, 9

process tracing, $13,31,45-7,64,148$, 211-12, 215, 223, 226, 242-3, 256, 259

Proksch, S. -O., 147, 273

prosopography, 48

public protests, 82

punctuated equilibrium theory, 124

Putnam, R., 170

QCA, see qualitative comparative analysis

Quaglia, L., 212

qualitative comparative analysis, 92-4

qualitative interviews, 79, 129, 146, 163

quantitative-oriented analysis, 117

Radaelli, C. M., 13, 104, 105, 108, 156, $160,190,206,207,211,212,214$, $223,242,253,255,256,258,260$, $317,318,319$

Ragin, C. C., 92

Rahat, G., 276

Rajulton, F., 229

Rasmussen, A., 149, 273
Rasmussen, M., 40, 44, 146, 148

rational choice theory, 27

rationalism, 31, 223

rationalist, $3,8,10,25,31,86,88,92$, $102,105,107,157,310-11$

Raunio, T., 271, 272

Ray, L., 187, 188, 191

Rees, T., 90

referendum, 247, 283-5, 291

reflexivity, 19, 30, 32

regionalism, 297

regulatory impact assessment, 260

regulatory state, 253, 256

Reh, C., 149

Reif, K., 270

Rein, M., 107

Reisigl, M., 109

research agenda, 3, 5, 15, 105, 185, 207, 267, 297-8, 304, 313

Research Agendas in EU Studies, 237

research design

biofuels policy, 92-4

bottom-up, 211, 241-2

CAP making, 45-7

casual, 224-5

coding, 127-9

comparative, 62-3, 66, 97, 244-5, 316

comparative temporal analysis, 245-7

constitutive, 224-5

counterfactual analysis, 243-4

cross-sectional, 316

cross-sectional case study, 66

CSDP, 94-6

diffusion approach, 258-60

discourse analysis, 127-9

discursive, 110

EU environmental policy, 90-2

Eurobarometer opinion poll data, 66

experimental, 66, 316

guidelines to innovative, 47-9, 97-8,

149-50, 230-2, 247-9, 274-6

history and archives, 41-2

history sourcing, 42-5

innovative, 66-8, 132-3, 230-2, 247-9

longitudinal, 316

mixed-method, 66, 149-50, 316-17

multilevel analysis, 260-2

multi-method, 316

network approach, 256-8

normative power, 224-30 
research design - continued operationalisation and, 105-6

process tracing, 242-3

process tracing, $45-7$

qualitative, 60

sequential, 317

study of causality, 292

top-down, 241-2

transdisciplinary, 4-6

trinity of power, 225-6

tripartite analysis, 226-7

research method

cross-disciplinary, 5

group observation, 318

innovations in, 232

interviews, 318

preferred choice, 313

qualitative, 66, 137

quantitative, $66,137-8$

questionnaires, 318

surveys, 318

transdisciplinary, 5

research purpose, 4, 8, 97, 230, 314-16, 318

research strategy

case study, 315

comparative studies, 315

concurrent (or parallel), 316

cross-sectional design, 316

descriptive, 315

design, 315-18

experimental design, 316

exploratory, 315

group observation, 318

implications, 311

individual interviews, 318

longitudinal design, 316

method, 318-20

mixed-method designs, 316-17

multi-method designs, 316

nature, 311

purpose, $314-15$

questionnaires, 318

sequential exploratory approach, 317

sequential mixed methods, 317

surveys, 318

textual and document analysis, 318

unobtrusive methods, 319

Rhodes, R. A. W., 169, 252, 256

RIA, see regulatory impact assessment
Ricci, D. M., 20

Richardson, D., 269

Richmond, O., 228

Rihoux, B., 92

Ringe, N., 148

Risse, T., 55, 56, 57, 58, 59, 60, 62, 63, $66,68,74,75,103,155,157,185$, 186, 206, 208, 209, 223, 238, 253

Rittberger, B., 8, 38, 148, 253, 254

Robinson, N., 304

Roccas, S., 191

Roe, E., 108

Rohrschneider, R., 269

Rokkan, S., 267, 269, 275

Roland, G., 272

roll-call data, 272-3

roll-call votes, 138, 146, 148-9, 272

Roma (minority group), 74

Romania, 162

Romano, A., 48

Rootes, C., 269

Rosamond, B., 4, 7, 10, 18, 21, 22, 24, $30,32,55,56,67,94,105,124,237$, 239, 297, 301, 309, 313

Rozenberg, O., 275

Rubin's causal model (RCM), 284, 286

Ruggie, J. G., 25

Rumelili, B., 222

Rumford, C., 23, 248

Ruzza, C., 77

Sabatier, P. A., 86, 112, 154, 155

Sabel, C. F., 211, 255

Sachs, N. B., 189

Sætren, H., 156

Sandholtz, W., 239

Sandström, C., 269

Sarkozy, Nicolas, 114

Sartori, G., 18, 21, 29, 269

SAS, 318

Sasse, G., 223

Saurugger, S., 23, 24

S2B, see Seattle to Brussels

Sbragia, A., 303

Schäfer, A., 255

Scharpf, F. W., 74, 75, 169, 214, 255, 256, 288

Scheingold, S. A., 25, 26, 30

Scheipers, S., 228

Schengen agreement, 115 
Schimmelfennig, F., 74, 97, 174, 222, 223

Schmidt, V. A., 23, 75, 87, 103, 104, 105, $112,113,114,212,213,239$

Schmitter, P. C., 174

Schmitt, H., 269, 270

Schneider, C., 93

Schneider, G., 8, 28, 29, 137, 144, 145

Schneider, V., 239, 244

Schön, D. A., 107

Schouenborg, L., 248

Schout, A., 253, 254

Schuck, A. R. T., 282, 283

Schwartz-Shea, P., 18

Scott, J., 172, 257

Scully, R., 273

Sears, D. O., 191

Seattle to Brussels, 77-83

European identity, 79

findings, 79-80

formation of, 80

geography, 78

mapping, 79

protest networks, 78

Seattle protests, 80

second order election thesis, 270

Sedelmeier, U., 97, 222

Seidel, K., 38, 46

Seidendorf, S., 115

Sekhon, J. S., 286

self-reported identification, 187

Selten, R., 290

Serritzlew, S., 292

sexuality, 96

shades of grey, 40, 48

Shapiro, L., 27

Sharman, J. C., 259

Shaw, T. M., 300

shift of loyalties, 55

Shipan, C. R., 259

Shore, C., 184, 185, 186

Sicurelli, D., 228

Sides, J., 185, 186

Sikkink, K., 223

Sil, R., 216

Simon, A. F., 288

single case studies, 64, 97, 271

Single European Act, 299

Single European Market, 240 single policy study, $11,86-8$

benefits of, 89

biofuels directive, 88

biofuels policy, 92-4

common use of, 86

CSDP, 94-6

delimitations of, 88

diverse and productive approaches, 87

environmental policy, 86-92

gender mainstreaming, 89-90

multilevel, 88

multi-state, 88

policy development tracing, 87

research questions, 87-96

sectorisation, 89

social group dynamics, 98

theoretical positions, 87-96

Sjöblom, G., 268

Sjursen, H., 223

Sköldberg, K., 229, 230

Slapin, J. B., 273

Slovenia, biofuels policy, 93

small-n, 25, 64, 137, 198, 244, 246, 269 , $271,273,315$

Smith, A., 189, 190

Smith, K. E., 222

Smith, M. E., 222

Smith, N., 239

Smith, S., 225

SNA, see social network analysis

Sniderman, P. M., 287

Snow, D. A., 106, 107

social categorisation theory, 186

social constructivism, 222

social identity theory, 186,189

social movement, 73, 77-9, 81, 90, 104, 106, 112, 206

social network analysis, $12,65,81$, $171-2,174,178,256-8$

social policy, 161,255

social solidarity, 228

Social Trends Survey 2011, 193

sociological institutionalism, 222

Söderbaum, F., 297, 299, 300, 302, 303, 304, 305, 306

soft governance, 10, 252-3, 255-6, 260, 262, 316

Sørensen, E., 169

Soule, D. P. J., 63

source criticism, 42 


\section{Copyrighted material - 9780230363052}

Southern African Development

Community, 300

Soviet Union, collapse of, 55

Soysal, Y. N., 74

Spaak, Paul-Henri, 44

Spain

\section{Basque politics in, 63 \\ EU membership, 64 \\ European integration, 62 \\ national identity, 62}

post-Franco devolution settlement, 64

re-creation of Basque institutions, 64 spatial lag, 259

spatial turn, 48-9, 312

Spirova, M., 269

Spohn, W., 186

SPSS, 232, 318

Stacey, J., 8

Stata, 232, 261, 318

state-civil society relationships, 6

state-like characteristics, 7

Statham, P., 75, 104, 106

statistical methods, 150, 274, 276, 317

Steedman, C., 42

Steele, F., 261

Steenbergen, M. R., 187, 188, 191, 260, 292

Stephenson, P. J., 125

Stimson, J. A., 19

Stolfi, F., 212

Strange, M., 11, 72, 78

Strøm, K., 268, 275

structural funding, 156, 163, 190

structural funds, 162, 164

Stryker, S., 191

subsidiarity principle, 254

Sulkin, T., 288

surveys

agendas assessing, 130

assumptions, 130

comparative, 187

cross-sectional, 191

Eurobarometer, 59, 187, 194

expert, 318

online, 316

standardised questionnaires, 129

use of, 130

Svedrup, H., 154

Sweden, neo-corporatist political systems, 240
Sweet, A. S., 239

Switzerland, 244

symbols, 13, 58-9, 62, 95, 184-92, 196-8 symbolic cue, 195, $199 f$

symbolic visual cues, 189

Sznaider, N., 248

Taggart, P., 56

Tajfel, H., 186, 191

Tallberg, J., 92, 256

Tannam, E., 63

Tarrow, S., 9

tax harmonisation, 108

Taylor, S., 191

Telò, M., 307

temporal sorting model, 90-1

territorial politics, 11, 56, 64

testable hypotheses, 8

TFEU, see Treaty of the Functioning of the EU

Thatcher, M., 211, 212, 255, 256

Thedvall, R., 133

Thelen, K., 157

theoretical innovations of social theory, 222

theoretical schools of EU studies, $24 f$

Thistlethwaite, D. L., 292

Thomassen, J., 269

Thompson, D., 144, 148, 288

Thomson, R., 18, 144

Thomson Reuters Social Science Citation Index, 18

throughput, 74-5

Tindall, D. B., 257

Titiunik, R., 286

Tocci, N., 63

Töller, A. E., 207, 215

Tonra, B., 103, 223

top-down and bottom-up, 13, 212

Torfing, J., 162, 169

Tortell, L., 222, 228

Toscano, J. V., 26

Tosun, J., 175, 226

Tracy, Michael, 44

Trampusch, C., 212

Treaties

Lisbon Treaty, 6, 148, 176

Maastricht Treaty, 61, 291

Treaty of Rome, 39

Treaty of the Functioning of the EU, 176 
treaty ratification, 104, 106

Treib, O., 154, 156, 158

Trenz, H. -J., 104, 189, 288

trinity of power, $13,224-8$

tripartite analysis, $13,224,226-8$

Trondal, J., 60, 155, 213, 215

Trubek, D., 252

Trust game, $290 t$

Tsarouhas, D., 239

Tsebelis, G., 27, 92, 145, 147, 148

Turner, J. C., 186

unemployment, 108

United Kingdom (Britain)

adaptational pressures, 208

civic and cultural conception of identity, 59

EU environmental policy, 158

European integration, 62, 191

national identity, 62

parliamentary debates, 62

terrorist attack, 61

Universal Declaration of Human Rights, 226

UN peacekeeping missions, 226

UN Security Council, 96

Urfalino, P., 213

Valbjørn, M., 312

Van Apeldoorn, B., 126, 132

van der Vleuten, A., 88

Van Dijk, T., 105, 109

Van Horn, C. E., 155

van Kersbergen, K., 57

van Keulen, M., 92

Van Langenhove, L., 297, 301, 303

Van Meter, D., 155

van Spanje, J., 271

variegated neoliberalism, 126, 241, 248

varieties of capitalism, 240-1, 249

Varsori, A., 38, 39

Vauchez, A., 38, 48

Vaus, David de, 230, 315

Verba, S., 185

Verdier, D., 239, 244

Verloo, M., 90

Versluis, E., 161

Vifell, Å., 163

Vink, M. P., 6

visual cues, 184, 189, 191, 194, 198
VoC, see varieties of capitalism

Vogler, J., 222

Volden, C., 259

von Wahl, A., 95

Vos, E., 255

voting, 137-8, 143-7, 149, 176, 272-3, 282,285

voting power indices, 142

Vresse, C. H. D., 283

Waever, O., 103

Wagenaar, H., 86

Wallace, H., 44, 68, 143, 144

Warleigh, A., 4, 5, 67

Warleigh-Lack, A., 7, 14, 32, 297, 301, 302, 303, 304, 306, 309, 313, 315

Warlouzet, L., 38

Wasserman, S., 172, 257

Webb, C., 87

Webb, P., 266

Weber, M., 225

Wegemann, C., 93

Weiner, A., 24, 55

Weisbein, J., 76

welfare state, 38-9, 108

welfarism, 47

Wellman, B., 257

Welsch, H., 73

Wendt, A., 25, 31

Werner report, 47

Whitaker, R., 269, 273

Whitefield, S., 269

White, J., 104, 187

Whitman, R., 222, 223, 224, 225, 315

Widgren, M., 145

Wildavsky, A., 155

Williams, K. C., 281, 282, 284, 289, 291

Wilson, T. D., 56, 287

Winter, D., 188, 193

Winzen, T., 147

Wittrock, J., 282

Wivel, D., 248

Wodak, R., 60, 62, 66, 109

Wolf, D., 256

Wolff, S., 222

Woll, C., 211, 306

Wong, R., 223

Woodward, A., 90

Wordsmith, 106

World Bank, 245 
342 Index

World Development Movement, 80

World Trade Organization (WTO), 73, $77-80,113,115,226$

Wurzel, R., 210

Xiarchogiannopoulou, E., 104

Yang, S., 256

Yanow, D., 18

Yardonova, N., 147

Yin, R. K., 88

Ylikoski, P., 213
Yordanova, N., 272

YouGov, 192

Youngs, R., 223

Zahariadis, N., 124

Zaiceva, A., 73

Zaller, J. R., 282

Zeitlin, J., 211, 255

Zielonka, J., 223

Zølner, M., 173

Zürn, M., 252 